\title{
UWARUNKOWANIA EFEKTYWNOŚCI EKONOMICZNEJ PRZEDSIĘBIORSTW PRZEMYSŁOWYCH W FAZIE WPROWADZENIA ICH CYKLU ŻYCIA
}

\author{
Mirosław Wasilewski \\ Katedra Finansów \\ Szkoła Główna Gospodarstwa Wiejskiego w Warszawie
}

Joanna Żurakowska-Sawa

Państwowa Szkoła Wyższa im. Papieża Jana Pawła II w Białej Podlaskiej

\begin{abstract}
Abstrakt. W opracowaniu określono syntetyczną miarę efektywności ekonomicznej przedsiębiorstw, dokonano określenia zmiennych determinujących jej poziom, a także wskazano kierunek oraz siłę ich wpływu na wielkość syntetycznej miary tej efektywności w przedsiębiorstwach przemysłowych. Czynnikami warunkującymi poziom efektywności ekonomicznej przedsiębiorstw znajdujących się $\mathrm{w}$ fazie wprowadzenia były uwarunkowania mikroekonomiczne o charakterze ilościowym. Wskaźnik rentowności aktywów oraz płynności bieżącej wywierały dodatni wpływ na wzrost efektywności ekonomicznej przedsiębiorstw znajdujących się w fazie wprowadzenia, natomiast wskaźnik relacji kapitału obrotowego netto do aktywów ogółem ujemnie oddziaływał na tą efektywność.
\end{abstract}

Słowa kluczowe: efektywność ekonomiczna przedsiębiorstwa, fazy cyklu życia przedsiębiorstwa.

\section{WSTĘP}

Funkcjonowanie przedsiębiorstwa w warunkach konkurencji rynkowej wiąże się z przemijaniem w czasie. Przebieg życia każdego przedsiębiorstwa można przedstawić przy wykorzystaniu koncepcji cyklu życia przedsiębiorstwa. W odniesieniu do przedsiębiorstwa koncepcja „cyklu życia” przyczynia się do lepszego poznania mechanizmów rozwoju, zrozumienia możliwości i konieczności jego „odradzania 
się" a także ma istotne znaczenie dla skuteczności działań w obszarze kierowania rozwojem przedsiębiorstwa [Platonoff, Sysko-Romańczuk 2009, s. 4]. W ostatnich dwóch dekadach można zauważyć, szczególnie w literaturze zagranicznej, coraz większy wzrost zainteresowania zastosowaniem teorii cyklu życia organizacji w badaniach z zakresu rachunkowości oraz finansów. Badania te dotyczyły m.in. czynników wewnętrznych i/lub zewnętrznych, umożliwiających identyfikacje faz cyklu życia [Dickinson 2011, s. 1969-1994], wypłaty dywidend [De Angelo, De Angelo, Stulz 2006, s. 227-254; Bulan, Subramanian, Tanlu 2007, s. 31-65], nakładów inwestycyjnych (np. Anthony, Ramesh 1992, s. 203-227] czy też rentowności [Dickinson 2011, s. 1969-1994; Warusawitharana 2012, s. 1-47].

Jednym $\mathrm{z}$ ważnych okresów $\mathrm{w}$ funkcjonowaniu przedsiębiorstwa jest faza wprowadzania, w której następuje szybkie tempo zmian organizacyjnych. Przedsiębiorstwa, które znajdują się w tej fazie to zarówno te, które dopiero rozpoczęły działalność, wchodząc na rynek z usługą lub produktem, jak również te, które dysponują już odpowiednim potencjałem zasobów i dostosowując się do szybko zmieniających się warunków rynkowych, wchodzą na rynek z innowacją biznesową. Dlatego też istotne jest określenie przez przedsiębiorstwo celów oraz sposób ich realizacji. Sprawne funkcjonowanie wymaga zatem wpisania działalności przedsiębiorstwa w traidę celów, tj. rozwój-efektywność-wartość [Borowiecki, Czaja, Jaki 1998, s. 13; Szczepankowski 2013, s. 125].

W przedstawianych w literaturze definicjach efektywności nie ma jednoznacznego podejścia, ale pomimo to pojęcie to stanowi istotne uwarunkowanie do przetrwania, czy też rozwoju przedsiębiorstwa. Efektywność jest pojęciem, na którym skupiają się zarządzający, planując, czy też realizując określone działania [OsbertPociecha 2010, s. 373]. W kontekście definicji efektywności istnieje uzasadniona potrzeba wyróżnienia pewnych kategorii, które wyodrębnia się ze względu na cel oraz możliwe do przyjęcia, w jego kontekście kryteria oceny rezultatu działania [Winkler 2010, s. 112]. W literaturze często pojęcie efektywności ekonomicznej jest stosowane zamiennie z terminem efektywność gospodarowania [Szymańska 2010, s. 156; Chęciński 2011, s. 28; Kulawik 2007, s. 4; Sobolewski 1987, s. 150], efektywność kosztowa [Kozuń-Cieślak 2011, s. 93], czy też wydajność ekonomiczna [Jaki 2006, s. 110].

Za podstawę teoretycznych, jak również praktycznych rozważań tematu efektywności działalności w ujęciu klasycznym powszechnie uznaje się zasadę racjonalnego gospodarowania [Barburski 2007, s. 9]. Efektywność ekonomiczna, zgodnie z tą zasadą określana jest poprzez odniesienie uzyskiwanych z działalności gospodarczej efektów do poniesionych nakładów, czy też nakładów do efektów [Milewski, Kwiatkowski (red.) 2005, s. 17; Michalak 2008, s. 55].

Zagadnienie uwarunkowań efektywności ekonomicznej należy rozpocząć od encyklopedyczno-słownikowego objaśnienia terminu „uwarunkowanie”. Według Skorupki [1985, s. 511] słowo „uwarunkowanie” rozpatrywane w kontekście roz- 
woju jest m. in. synonimem słowa „czynnik” lub „warunek”. W ujęciu encyklopedycznym [Petrozolin-Skowrońska 1997, s. 664] „warunek” to czynnik wyznaczający lub umożliwiający zaistnienie określonego zdarzenia (zjawiska, stanu rzeczy, cechy, itp.), albo też zwiększający jego prawdopodobieństwo (warunek sprzyjający), natomiast w ujęciu słownikowym [Skorupka, Auderska, Łempicka (red.) 1968, s. 101] „czynnik” to jedna z przyczyn danego zjawiska, jeden ze składników warunkujących coś, rozstrzygających o czymś. Zatem uwarunkowanie możemy rozumieć, jako pewną okoliczność, która determinuje coś.

Jak stwierdził Czechowski [1997, s. 37] tematyka uwarunkowań efektywności ekonomicznej przedsiębiorstwa nie jest dostatecznie zidentyfikowana w teorii ekonomii, jak również w praktyce gospodarczej. Dlatego, jak podkreśla, istnieje konieczność prowadzenia badań w tym kierunku. W swoich rozważaniach autor ten wskazał, że podejmowanie przez przedsiębiorstwo działań mających na celu wzrost efektywności zależy od:

1. Otoczenia dalszego, czyli warunków systemowo-instytucjonalnych, przede wszystkim: formy własności przedsiębiorstwa, celów jakie realizuje przedsiębiorstwo, liberalizację/deregulację gospodarki,

2. Otoczenia bliższego, czyli warunków rynkowych, przede wszystkim: zakresu konkurencji o charakterze wewnętrznym i zewnętrznym, stopnia zmonopolizowania produkcji, poziomu inflacji, rozwoju rynku kapitałowego,

3. Warunków wewnętrznych tworzonych w przedsiębiorstwie.

Warto zaznaczyć, że o ile otoczenie dalsze pozostaje w większości przypadków poza kontrolą przedsiębiorstwa, o tyle zarządzający przedsiębiorstwem mają już realny wpływ na relacje z otoczeniem bliższym i kształtowanie potencjału wewnętrznego przedsiębiorstwa.

\section{CEL I METODY BADAŃ}

Celem opracowania jest określenie zmiennych determinujących poziom syntetycznej miary efektywności ekonomicznej w spółkach giełdowych sektora przemysłu, znajdujących się w fazie wprowadzenia w ramach cyklu życia przedsiębiorstwa. Przeprowadzone badania objęły spółki notowane na Giełdzie Papierów Wartościowych (GPW) w Warszawie i według tam stosowanej klasyfikacji są zaliczane do sektora przemysłu. Okres badawczy obejmował lata 1999-2012. Dane zostały uzyskane z roczników giełdowych, jednostkowych rocznych sprawozdań finansowych dostępnych w bazie Notoria Servis, roczników statystycznych, na stronach Ministerstwa Rozwoju oraz Narodowego Banku Polskiego. Analizy statystyczne wykonano przy pomocy pakietu STATISTICA PL.

Badania miały charakter trzyetapowy. W etapie pierwszym dokonano podziału spółek, przypisując je do konkretnej fazy cyklu życia. W tym celu zastosowano 
model Dickinson [2011, s. 1969-1994] oparty na kombinacji znaków sald z przepływów pieniężnych na koniec roku obrotowego z trzech rodzajów działalności, tj. operacyjnej, finansowej i inwestycyjnej, które przedstawiają alokację zasobów oraz bieżące możliwości przedsiębiorstwa będące $\mathrm{w}$ interakcji z ich wyborami strategicznymi. Łącząc trzy znaki sald przepływów pieniężnych, otrzymano osiem możliwych kombinacji potencjalnie obserwowalnych w przepływach pieniężnych, które zostały przełożone na pięć teoretycznych faz cyklu życia przedsiębiorstwa. Za Dickinson [2011, s. 1969-1994], która zastosowała w swoich badaniach określone przez Gort i Klepper [1982, s. 630-653] pięć etapów cyklu życia na poziomie przedsiębiorstwa, tj. wprowadzenie, wzrost, dojrzałość, wstrząs oraz upadek w opracowaniu przyjęto ten schemat nazewnictwa faz.

Za Yan i Zhao [2010, s. 581] przyjęto, że fazy w cyklu życia przedsiębiorstwa nie są ze sobą połączone w sposób deterministyczny, czyli przykładowo po fazie dojrzałości może nastąpić faza spadku, czy też wzrostu. Jest to ważna koncepcyjnie zaleta, która wskazuje, iż przedsiębiorstwa mogą dynamicznie poruszać się pomiędzy fazami cyklu życia, co jest naturalną konsekwencją tego, iż ich rozwój jest pobudzany, jak i ograniczany przez wiele czynników wewnętrznych oraz zewnętrznych.

Drugim etapem badań było wyznaczenie syntetycznej miary efektywności ekonomicznej dla przedsiębiorstw znajdujących się w fazie wprowadzenia. Na podstawie rozważań teoretycznych oraz istniejących w literaturze opracowań badań w zakresie efektywności ekonomicznej, a przede wszystkim możliwości zebrania materiału źródłowego do przeprowadzenia porównawczej oceny efektywności ekonomicznej badanych przedsiębiorstw przemysłowych wybrano wstępnie 22 cząstkowe miary efektywności, które były zmiennymi wejściowymi. Wszystkie zmienne były stymulantami. Do wyznaczania zmiennej syntetycznej efektywności ekonomicznej zastosowano następujące kroki postępowania doboru zmiennych diagnostycznych:

1. Zbadano czy potencjalne zmienne charakteryzują się dostatecznie dużą zmiennością. W tym celu został wykorzystany współczynnik zmienności obliczany według następującego wzoru [Borkowski, Dudek, Szczęsny 2003, s. 62]: V

$$
V_{j}=\frac{S_{j}}{\overline{X_{J}}} \cdot 100 \%, \overline{X_{J}} \neq 0
$$

gdzie: $V_{j}$ - współczynnik zmienności, $S_{j}$ - odchylenie standardowe cechy $X, \bar{x}_{j}-$ wartość średnia cechy $X_{j}$.

Ze zbioru analizowanych zmiennych wyeliminowano cechy spełniające nierówność $\left|V_{j}\right| \leq V^{*}$, gdzie $V^{*}$ oznacza krytyczną wartość współczynnika zmienności. Jako wartość krytyczną przyjęto $V^{*}=0,10$ (10\%) co oznaczało, że cechy wykazywały zróżnicowanie statystycznie nieistotne, jeśli współczynnik zmienności $V_{j}$ nie przekraczał 10\% [Zeliaś 2002, s. 49]. 
2. Wyznaczono macierz korelacji pomiędzy zmiennymi. Do dyskryminacji zmiennych zastosowano metodę odwróconej macierzy, która polega na wyznaczeniu macierzy odwrotnej $\mathrm{R}^{-1}$ do macierzy $\mathrm{R}$. W macierzy $\mathrm{R}^{-1}$ elementy diagonalne przyjmują wielkości z przedziału $[1,+\infty)$, przy czym jeśli przekroczyły ustalony maksymalny poziom $\tilde{r}_{0}$ (często przyjmuje się, że $\tilde{r}_{0}=10$, to świadczy o wadliwym uwarunkowaniu numerycznym macierzy R. Dlatego też dokonano eliminacji tych zmiennych, dla których $\left|\tilde{r}_{j k}\right|>\tilde{r}_{0}$.

Otrzymany ze zbioru wejściowych zmiennych diagnostycznych zestaw zmiennych finalnych, które wyrażone były w różnych mianach, poddano normalizacji $\mathrm{w}$ celu ujednolicenia, co do rzędu wielkości. W badaniach zastosowano metodę unitaryzacji zerowanej [Kukuła 2000, s. 189-190]. Na podstawie znormalizowanego zbioru zmiennych wyznaczono abstrakcyjny obiekt, czyli wzorzec o wartościach najlepszych dla każdej zmiennej (dla stymulant jest to wartość maksymalna) i antywzorzec o wartościach najgorszych dla każdej zmiennej(dla stymulant jest to wartość minimalna). Następnie zbadano podobieństwo obiektów do abstrakcyjnego najlepszego obiektu, poprzez obliczenie odległości każdego obiektu od wzorca przy użyciu metryki euklidesowej, która wyrażona jest następującym wzorem [Suchecki 2010, s. 63]:

$$
d_{i o}=\sqrt{\sum_{j=1}^{m}\left(z_{i j}-z_{o j}\right)^{2}}, i=1,2, \ldots, n
$$

gdzie: $d_{i o}$ - odległość $j$-tego obiektu od wzorca, $z_{i j}$ - standaryzowana wartość $i$-tej cechy $w j$-tym obiekcie, $z_{o j}$ - wzorzec rozwoju.

Im zbudowana w ten sposób odległość $d_{i o}$ przyjmuje niższą wartość dla danej jednostki, tym wyższy jest poziom jej rozwoju. Otrzymane odległości stanowiły podstawę do obliczenia dla każdej jednostki (spółki) wartości syntetycznej miary efektywności ekonomicznej, czyli tzw. taksonomicznej miary rozwoju według następującego wzoru [Suchecki 2010, s. 63]:

$$
m_{i}=1-\frac{d_{i o}}{d_{o}}, i=1,2, \ldots, n
$$

gdzie: $d_{o}$ - odległość między wzorcem i antywzorcem rozwoju, przy czym miara rozwoju obliczona dla wzorca rozwoju równa jest jeden, a dla antywzorca - zero.

Miara rozwoju jest unormowana w przedziale [0;1] i charakteryzuje się tym, że jest nieujemna. Im bardziej wartość miary taksonomicznej jest bliższa jedności, tym dany obiekt rzeczywisty - spółka - osiąga wyższy poziom rozwoju. Natomiast poziom rozwoju obiektu - spółki - jest tym niższy, im bardziej wartość miary taksonomicznej zbliża się do zera [Czechowski 1997, s. 138]. 
W trzecim etapie badań do oszacowania parametrów modelu ekonometrycznego mającego na celu określenie uwarunkowań z zakresu otoczenia makroekonomicznego, jak i charakterystyk mikroekonomicznych przedsiębiorstw determinujących zmiany efektywności ekonomicznej spółek giełdowych znajdujących się w fazie wprowadzenia oraz wskazania siły i kierunku wpływu tych czynników wykorzystano oszacowany metodą najmniejszych kwadratów ekonometryczny liniowy model regresji wielorakiej postaci: $Y=a_{0}+a_{1} X_{1}+a_{2} X_{2}+\ldots a_{k} X_{k^{\prime}}$ gdzie: $Y$ oznacza zmienną objaśnianą (zależną), $X_{1}, X_{2}, \ldots X_{k}$ - zmienne objaśniające (niezależne), natomiast $a_{0}, a_{1}, \ldots a_{k}$ - oszacowane metodą najmniejszych kwadratów wartości parametrów strukturalnych modelu. Za zmienną objaśnianą (zależną) w modelu przyjęto wartość syntetycznej miary efektywności ekonomicznej przedsiębiorstw znajdujących się w fazie wprowadzenia $(Y)$. Początkowo zbiór potencjalnych zmiennych objaśniających obejmował czynniki makroekonomiczne (wskaźniki sytuacji makroekonomicznej) oraz czynniki mikroekonomiczne ilościowe ${ }^{1}$, w dalszej kolejności wybrano te zmienne, której były najmocniej skorelowane ze zmienną objaśnianą, a jednocześnie słabo skorelowane z pozostałym zmiennymi objaśniającymi [Stanisz 2007, s. 138]. Wykorzystano w tym celu regresję krokową postępującą, która zakłada kolejne krokowe dołączanie do listy zmiennych objaśniających tych zmiennych, które mają w danym kroku najistotniejszy wpływ na zmienną objaśnianą [Stanisz 2007, s. 137]. W uzyskanych tą metodą modelach pojawiło się wiele zmiennych objaśniających, które były nieistotne statystycznie (dołączenie do danego zestawu zmiennej objaśniającej może spowodować brak istotności innej, wcześniej dołączonej zmiennej). Celem dalszej eliminacji zmiennych nieistotnych statystycznie w bazowych modelach zastosowano regresję krokową wsteczną, której założeniem jest kolejne krokowe usuwanie z modelu zmiennych, które w danym kroku mają najmniej istotny wpływ na zmienną objaśnianą. Taki sposób postępowania prowadzony był aż do uzyskania najlepszego modelu, w którym wszystkie zmienne były istotne statystycznie [Stanisz 2007, s. 159].

Po oszacowaniu modelu przeprowadzono weryfikację, która miała na celu sprawdzenie prawdziwości założeń metody najmniejszych kwadratów. Proces weryfikacji obejmował badanie własności reszt (składników losowych) modelu regresji, czyli zgodności z rozkładem normalnym (test Shapiro-Wilka) oraz występowanie zjawiska autokorelacji reszt modelu (test Durbina Watsona).

\footnotetext{
${ }^{1}$ Wskaźniki opisujące strukturę aktywów i pasywów, płynności finansowej, sprawność zarządzania kapitałem obrotowym, zdolność majątku do generowania zysku, wartość aktywów i stopień ich umorzenia, wartość aktywów obrotowych, wartość przychodów ze sprzedaży, zysk/stratę z poszczególnych rodzajów działalności, liczbę zatrudnionych, kapitalizację spółki.
} 


\section{WYNIKI BADAŃ}

Do fazy wprowadzenia w ramach cyklu życia przedsiębiorstwa, na podstawie modelu Dickinson [2011, s. 1974], przyporządkowane zostały spółki, w których występowały ujemne przepływy operacyjne oraz inwestycyjne, przy dodatnim strumieniu finansowym. Z reguły taki wariant znaków z poszczególnych rodzajów działalności dotyczy przedsiębiorstw młodych, rozwijających się, jak również przeprowadzających restrukturyzację. W badanym okresie takich przypadków było 10,6\%, które można przyporządkować do fazy wprowadzenia, tj. 33 obserwacje (tabela 1). Wariant z takimi saldami przepływów pieniężnych nie wystąpił w 2002 roku, natomiast najwięcej przedsiębiorstw odnotowało taką sytuację w 2006 roku (5 spółek). Były to przedsiębiorstwa działające w sektorze: przemysłu elektromaszynowego (1 spółka), przemysłu lekkiego (1 spółka), przemysłu materiałów budowlanych (1 spółka), przemysłu metalowego (2 spółki) oraz przemysłu motoryzacyjnego (1 spółka).

TABELA 1. Liczba obserwacji według sektorów w fazie wprowadzenia cyklu życia przedsiębiorstwa

\begin{tabular}{|c|c|c|c|c|c|c|c|}
\hline \multirow{2}{*}{ Lata } & \multicolumn{6}{|c|}{ Sektor* } & \multirow{2}{*}{ Razem } \\
\hline & $E$ & $\mathrm{~L}$ & MB & $M$ & MOT & $\mathrm{S}$ & \\
\hline 1999 & - & - & - & 1 & - & - & 1 \\
\hline 2000 & - & - & - & - & - & 2 & 2 \\
\hline 2001 & - & 1 & - & - & 1 & 1 & 3 \\
\hline 2002 & - & - & - & - & - & - & - \\
\hline 2003 & - & - & 1 & - & - & 1 & 2 \\
\hline 2004 & - & - & 1 & 1 & - & 1 & 3 \\
\hline 2005 & - & - & - & 2 & - & 1 & 3 \\
\hline 2006 & 1 & - & 1 & 2 & 1 & - & 5 \\
\hline 2007 & 1 & - & 1 & 1 & 1 & - & 4 \\
\hline 2008 & - & - & 1 & - & - & - & 1 \\
\hline 2009 & - & - & 1 & 1 & - & - & 2 \\
\hline 2010 & - & - & - & 1 & - & - & 1 \\
\hline 2011 & 1 & - & 1 & - & - & 2 & 4 \\
\hline 2012 & 1 & - & - & 1 & - & - & 2 \\
\hline Częstość występowania & 4 & 1 & 7 & 10 & 3 & 8 & 33 \\
\hline
\end{tabular}

*E - przemysł elektromaszynowy, L - przemysł lekki, MB - przemysł materiałów budowlanych, M - przemysł metalowy, MOT - przemysł motoryzacyjny, S - przemysł spożywczy.

Źródło: opracowanie własne.

Budowę syntetycznej miary efektywności ekonomicznej dla przedsiębiorstw, które zostały przypisane do fazy wprowadzenia rozpoczęto od redukcji formalno - statystycznej wybranych wstępnie cząstkowych miar efektywności. Stwierdzono, że współczynniki zmienności wahają się od około (-551\%) do około 757\% 
(tabela 2). Największe zróżnicowanie przejawiało się w przypadku rentowności operacyjnej sprzedaży $(757,3 \%)$, natomiast najmniejsze dla wskaźnika opłacalności sprzedaży $(13,4 \%)$.

Analizując kryterium doboru zmiennych $\left(\left|V_{j}\right| \leq V^{*}\right)$, należy stwierdzić, że żadnej z potencjalnych cech diagnostycznych nie wyeliminowano z badania, gdyż obliczone dla nich współczynniki zmienności były w większości bardzo wysokie. W kolejnym etapie wyznaczono macierz korelacji między zmiennymi diagnostycznymi, na podstawie, której wyznaczono macierz odwrotną (tabela 3). $\mathrm{Z}$ zestawu zmiennych uzyskanej macierzy odwrotnej wyeliminowano 16 zmiennych, dla których elementy diagonalne (wartości na szarych polach na głównej

TABELA 2. Współczynnik zmienności dla zmiennych diagnostycznych w fazie wprowadzenie

\begin{tabular}{|c|c|}
\hline Zmienna diagnostyczne & $\begin{array}{l}\text { Współczynnik } \\
\text { zmienności (\%) }\end{array}$ \\
\hline Rentowność aktywów (ROA) & 380,87 \\
\hline Rentowność kapitału własnego (ROE) & 477,56 \\
\hline Rentowność sprzedaży (RS) & 82,70 \\
\hline Rentowność sprzedaży netto (RS netto) & 312,43 \\
\hline Rentowność sprzedaży brutto (RS brutto) & 289,55 \\
\hline Rentowność operacyjna sprzedaży (ROS) & 757,29 \\
\hline Gotówkowa rentowność sprzedaży (GRS) & 656,50 \\
\hline Rentowność operacyjna (RO) & 254,71 \\
\hline $\begin{array}{l}\text { Rentowność aktywów ustalana przy wykorzystaniu zysku z działalności } \\
\text { operacyjnej }\left(\mathrm{ROA}_{0}\right)\end{array}$ & 243,90 \\
\hline $\begin{array}{l}\text { Rentowność aktywów ustalana przy wykorzystaniu } \\
\text { tzw. zdolności do samofinansowania }\left(\mathrm{ROA}_{\mathrm{s}}\right)\end{array}$ & 134,29 \\
\hline Rentowność aktywów trwałych(RAT) & 506,30 \\
\hline Rentowność aktywów obrotowych (RAO) & 346,97 \\
\hline Wydajność pracy zatrudnionego (WPZ) & 114,68 \\
\hline Wskaźnik produktywności aktywów ogółem $\left(\mathrm{P}_{\mathrm{A}}\right)$ & 71,82 \\
\hline Wskaźnik produktywności aktywów trwałych $\left(\mathrm{P}_{\mathrm{AT}}\right)$ & 95,85 \\
\hline Wskaźnik produktywności majątku obrotowego $\left(\mathrm{P}_{\mathrm{MO}}\right)$ & 56,72 \\
\hline Wskaźnik produktywności kapitałów własnych $\left(\mathrm{P}_{\mathrm{KW}}\right)$ & 89,34 \\
\hline Produktywność rzeczowych aktywów trwałych $\left(\mathrm{P}_{\mathrm{RZAT}}\right)$ & 262,82 \\
\hline Efektywność wykorzystania środków trwałych $\left(\mathrm{E}_{\mathrm{ST}}\right)$ & 174,65 \\
\hline Wskaźnik opłacalności sprzedaży (OS) & 13,38 \\
\hline Wskaźnik zyskowności jednej akcji (EPS) & 384,85 \\
\hline Mnożnik rynkowy (MV/EBIT) & $-551,44$ \\
\hline
\end{tabular}

Źródło: opracowanie własne. 
przekątnej) były wyższe od $10\left(\left|\tilde{r}_{j k}\right|>\tilde{r}_{0}\right.$, gdzie $\left.\tilde{r}_{0}=10\right)$ Do usuniętych zmiennych

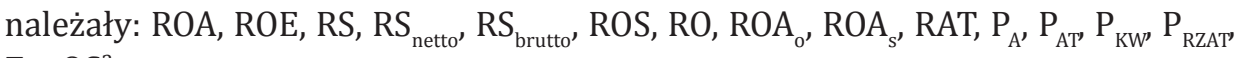
$\mathrm{E}_{\mathrm{ST}}, \mathrm{OS}^{2}$.

Po eliminacji zmiennych otrzymano nową zredukowaną macierz odwrotną, w której wszystkie elementy diagonalne były mniejsze od 10, i na tej podstawie uzyskano ostateczny zbiór zmiennych diagnostycznych, które zostały wykorzystane do budowy miary syntetycznej efektywności ekonomicznej dla przedsiębiorstw znajdujących się w fazie wprowadzenia.

Wyznaczona syntetyczna miara efektywności ekonomicznej umożliwiła otrzymanie informacji dotyczących poziomu efektywności ekonomicznej spółek znajdujących się w fazie wprowadzenia (tabela 4). Cztery przedsiębiorstwa o najwyższym poziomie syntetycznej miary efektywności ekonomicznej są to spółki działające w sektorze przemysłu motoryzacyjnego (w roku 2001), materiałów budowlanych (w roku 2003), spożywczego (w roku 2011), i elektromaszynowego (w roku 2007). Z kolei cztery przedsiębiorstwa, które uzyskały najniższy w badanej grupie poziom efektywności ekonomicznej, to te działające w sektorze przemysłu materiałów budowlanych (w roku 2007), metalowym (w latach 2005 i 2006) i motoryzacyjnym (w roku 2007).

W celu określenia udziału poszczególnych zmiennych diagnostycznych określających efektywności ekonomiczne cząstkowe w budowie syntetycznej miary efektywności ekonomicznej przedsiębiorstw znajdujących się w fazie wprowadzenia, obliczono współczynniki korelacji cząstkowej pomiędzy tymi zmiennymi diagnostycznymi a zmienną syntetyczną efektywności ekonomicznej (tabela 5). Największy udział, na podstawie korelacji cząstkowej, w budowie syntetycznej miary efektywność ekonomicznej przedsiębiorstw znajdujących się w fazie wprowadzenia miała rentowność aktywów obrotowych $(0,892756)$, wydajność pracy zatrudnionego $(0,834171)$, wskaźnik produktywności majątku obrotowego $(0,726995)$, a w dalszej kolejności mnożnik rynkowy $(0,538696)$ i wskaźnik

\footnotetext{
${ }^{2}$ Gotówkową rentowność sprzedaży (GRS) - obliczana, jako relacja przepływów pieniężnych netto do przychodów netto ze sprzedaży produktów, towarów i materiałów; rentowność aktywów obrotowych (RAO) - obliczana, jako relacja zysku netto do aktywów obrotowych; wydajność pracy zatrudnionego (WPZ) - obliczana, jako relacja przychodów netto ze sprzedaży produktów, towarów i materiałów do przeciętnej liczby zatrudnionych w przeliczeniu na pełne etaty; wskaźnik produktywności majątku obrotowego $\left(\mathrm{P}_{\mathrm{MO}}\right)$ - obliczany, jako relacja przychodów netto ze sprzedaży produktów, towarów i materiałów do stanu aktywów obrotowych; wskaźnik zyskowności jednej akcji (EPS) - obliczany jako relacja zysku netto do przeciętnej liczby wyemitowanych akcji; mnożnik rynkowy (MV/EBIT) - obliczany, jako relacja rynkowej wartości kapitału własnego do zysku z działalności operacyjnej.
} 


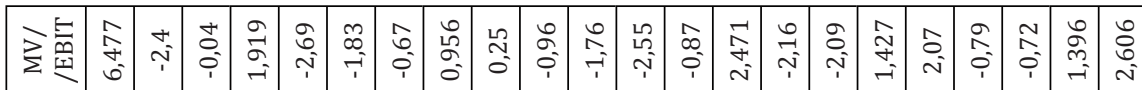

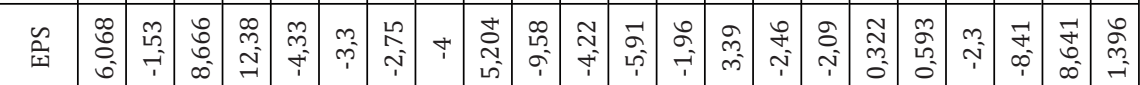

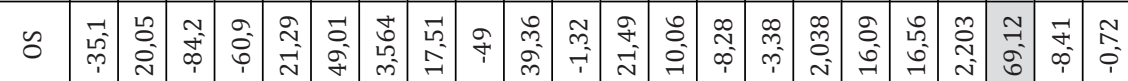
赵

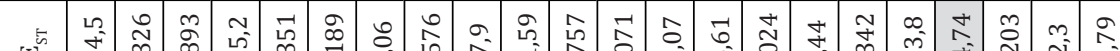

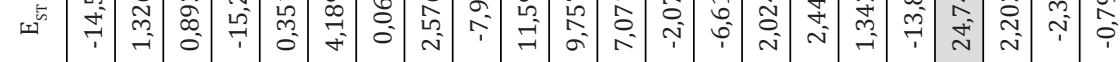

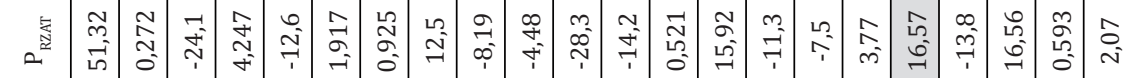

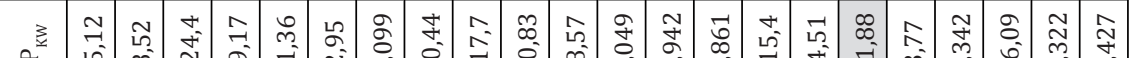

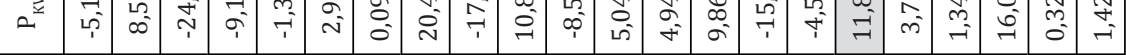

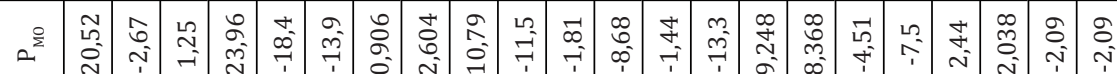

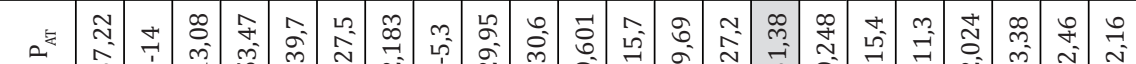

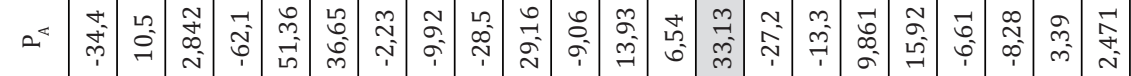

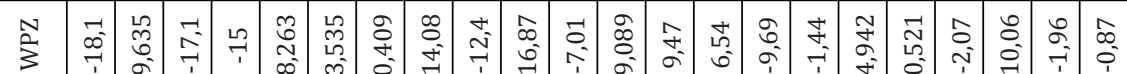

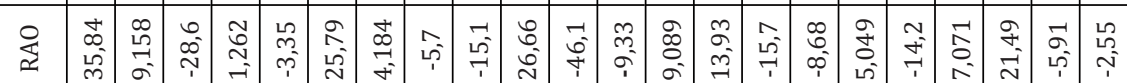

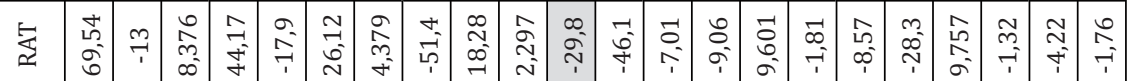

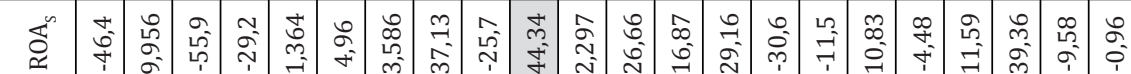

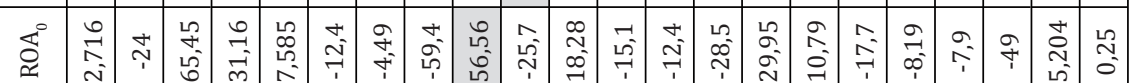

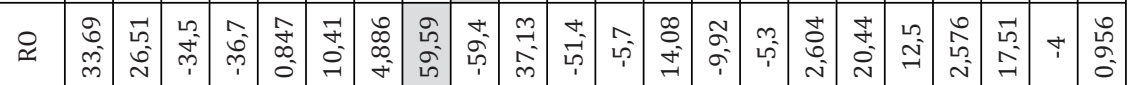

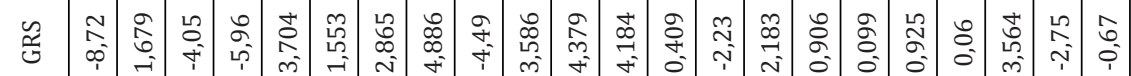

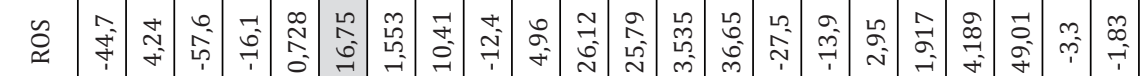

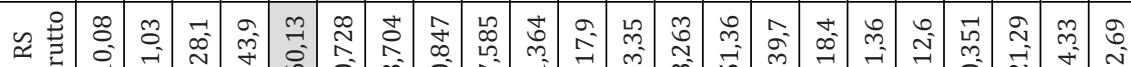

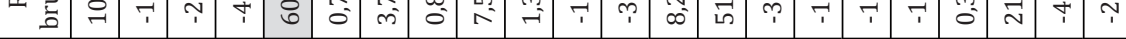

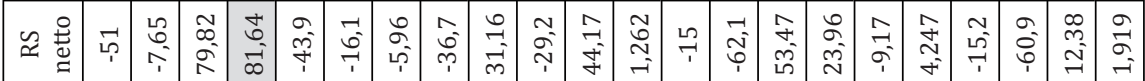

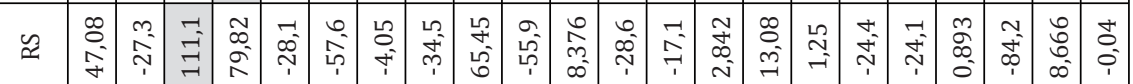

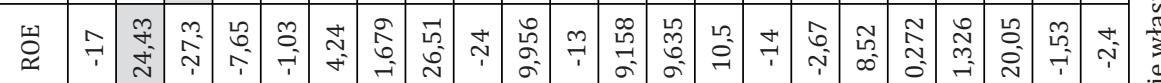

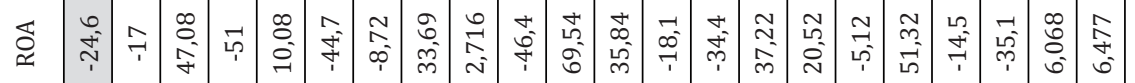

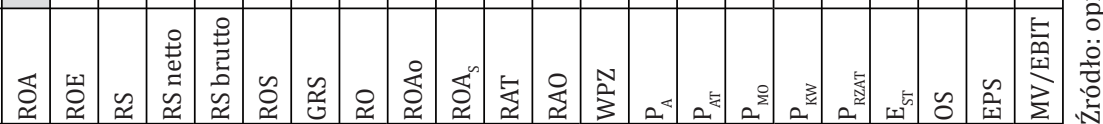


TABELA 4. Poziom syntetycznej miary efektywności ekonomicznej oraz ranking przedsiębiorstw według poziomu miary efektywności ekonomicznej spółek znajdujących się w fazie wprowadzenia

\begin{tabular}{|c|c|c|c|c|}
\hline Nazwa spółki & Sektor & Lata & $\begin{array}{l}\text { Poziom syntetycznej } \\
\text { miary efektywności } \\
\text { ekonomicznej }\end{array}$ & $\begin{array}{l}\text { Pozycja } \\
\text { w } \\
\text { rankingu }\end{array}$ \\
\hline Alchemia & Metalowy & 1999 & 0,332 & 20 \\
\hline Kruszwica & \multirow{2}{*}{ Spożywczy } & \multirow{2}{*}{2000} & 0,318 & 25 \\
\hline Pepees & & & 0,404 & 5 \\
\hline Pepees & Spożywczy & \multirow{3}{*}{2001} & 0,332 & 21 \\
\hline Groclin & Motoryzacyjny & & 0,450 & 1 \\
\hline Skotan & Lekki & & 0,327 & 23 \\
\hline Pepees & Spożywczy & \multirow{2}{*}{2003} & 0,335 & 19 \\
\hline Rovese & Materiałów budowlanych & & 0,438 & 2 \\
\hline Kruszwica & Spożywczy & \multirow{3}{*}{2004} & 0,382 & 11 \\
\hline Hutmen & Metalowy & & 0,306 & 27 \\
\hline Rovese & Materiałów budowlanych & & 0,383 & 10 \\
\hline Mieszko & Spożywczy & \multirow{3}{*}{2005} & 0,320 & 24 \\
\hline Alchemia & \multirow{2}{*}{ Metalowy } & & 0,229 & 31 \\
\hline Hutmen & & & 0,349 & 17 \\
\hline Groclin & Motoryzacyjny & \multirow{5}{*}{2006} & 0,350 & 16 \\
\hline Alchemia & \multirow{2}{*}{ Metalowy } & & 0,228 & 32 \\
\hline Hutmen & & & 0,390 & 8 \\
\hline Rovese & Materiałów budowlanych & & 0,360 & 14 \\
\hline Amica & Elektromaszynowy & & 0,331 & 22 \\
\hline Groclin & Motoryzacyjny & \multirow{4}{*}{2007} & 0,269 & 30 \\
\hline Hutmen & Metalowy & & 0,398 & 7 \\
\hline Ropczyce & Materiałów budowlanych & & 0,166 & 33 \\
\hline Kopex & Elektromaszynowy & & 0,409 & 4 \\
\hline Rovese & Materiałów budowlanych & 2008 & 0,382 & 11 \\
\hline Hutmen & Metalowy & \multirow{2}{*}{2009} & 0,317 & 26 \\
\hline Rovese & Materiałów budowlanych & & 0,336 & 18 \\
\hline Alchemia & Metalowy & 2010 & 0,399 & 6 \\
\hline Kruszwica & \multirow{2}{*}{ Spożywczy } & \multirow{4}{*}{2011} & 0,436 & 3 \\
\hline Pepees & & & 0,277 & 29 \\
\hline Rovese & Materiałów budowlanych & & 0,284 & 28 \\
\hline Kopex & Elektromaszynowy & & 0,369 & 13 \\
\hline Hutmen & Metalowy & \multirow{2}{*}{2012} & 0,388 & 9 \\
\hline Kopex & Elektromaszynowy & & 0,358 & 15 \\
\hline
\end{tabular}

Źródło: opracowanie własne. 
TABELA 5. Korelacje cząstkowe dla zmiennej syntetyczna efektywność ekonomiczna przedsiębiorstw znajdujących się w fazie wprowadzenia

\begin{tabular}{|l|c|}
\hline Zmienne diagnostyczne & Cząstkowa korelacja \\
\hline Gotówkową rentowność sprzedaży (GRS) & 0,323332 \\
\hline Rentowność aktywów obrotowych (RAO) & 0,892756 \\
\hline Wydajność pracy zatrudnionego (WPZ) & 0,834171 \\
\hline Wskaźnik produktywności majątku obrotowego (P ${ }_{\text {MO }}$ ) & 0,726995 \\
\hline Wskaźnik zyskowności jednej akcji (EPS) & 0,474469 \\
\hline Mnożnik rynkowy (MV/EBIT) & 0,538696 \\
\hline
\end{tabular}

Źródło: opracowanie własne.

zyskowności jednej akcji $(0,474469)$. Najniższy udział miała gotówkowa rentowność sprzedaży $(0,323332)$.

Kolejnym etapem badań było zbudowanie liniowego modelu regresji wielorakiej, opisującego syntetyczną miarę efektywności ekonomicznej przedsiębiorstw znajdujących się w fazie wprowadzenia w zależności od czynników makroekonomicznych i mikroekonomicznych. Wyniki estymacji parametrów tego modelu przedstawia tabela 6.

Otrzymany liniowy model opisujący efektywność ekonomiczną przedsiębiorstw przemysłowych w fazie wprowadzenia jest statystycznie istotny $(F=16,00670$; $\mathrm{p}=0,000003)$. Również analiza miar dopasowania, a także własności reszt potwierdza poprawność oszacowanego modelu. Współczynnik determinacji $\mathrm{R}^{2}$ wskazuje, że 62\% wariancji zmiennej objaśnianej zostało wyjaśnione przez zmienne uwzględnione w modelu. Wyniki testu Shapiro-Wilka na poziomie istotności 0,05 pozwoliły potwierdzić, że reszty modelu mają rozkład normalny ( $\mathrm{p}=0,39452)$. Wartość statystyki testowej Durbina Watsona (DW=2,212439) pozwala wnioskować, iż w otrzymanym modelu brak jest autokorelacji reszt.

Istotnymi statystycznie zmiennymi objaśniającymi(wartości p-value spełniały warunek p < 0,05), kształtującymi poziom syntetycznej miary efektywności ekonomicznej przedsiębiorstw znajdujących się w fazie wprowadzenia w modelu jest: rentowność aktywów, relacja kapitału obrotowego netto do aktywów ogółem oraz wskaźnik bieżącej płynności finansowej. Największy wpływ na poziom efektywności ekonomicznej przedsiębiorstw przemysłowych w fazie wprowadzenia miała relacja kapitału obrotowego netto do aktywów ogółem (świadczy o tym najwyższa wartość bezwzględna unormowanego współczynnika regresji). Wraz ze wzrostem relacji kapitału obrotowego netto do aktywów ogółem efektywność ekonomiczna przedsiębiorstw znajdujących się w fazie wprowadzenia malała. Zatem potwierdziła się zależność, że im wyższy jest poziom kapitału obrotowego netto, tym niższa osiągana efektywność ekonomiczna [Parkitna, Zięba 2009, s. 158; Zimon 2014, s. 595]. Utrzymywanie przewagi aktywów obrotowych nad 
TABELA 6. Wyniki estymacji parametrów modelu liniowego opisującego efektywność ekonomiczną przedsiębiorstw przemysłowych będących w fazie wprowadzenia

\begin{tabular}{|l|c|c|c|c|c|}
\hline Zmienna & $\begin{array}{c}\text { Unormowany } \\
\text { współczynnik } \\
\text { beta }\end{array}$ & $\begin{array}{c}\text { Błąd } \\
\text { standard. }\end{array}$ & $\begin{array}{c}\text { Współ. } \\
\text { regresji } \\
\text { beta (b) }\end{array}$ & Statystyka t & p-value \\
\hline Rentowność aktywów & 0,601199 & 0,119410 & 0,888091 & 5,03475 & 0,000023 \\
\hline $\begin{array}{l}\text { Kapitał obrotowy } \\
\text { netto/aktywa ogółem }\end{array}$ & $-0,676536$ & 0,130041 & $-0,258401$ & $-5,20248$ & 0,000014 \\
\hline $\begin{array}{l}\text { Wskaźnik płynności } \\
\text { bieżącej }\end{array}$ & 0,564632 & 0,124699 & 0,015519 & 4,52797 & 0,000094 \\
\hline Wyraz wolny & & 0,307051 & 24,33682 & 0,000000 \\
\hline Współczynnik korelacji wielokrotnej R & & & 0,79 \\
\hline Współczynnik determinacji R ${ }^{2}$ & & & 0,62 \\
\hline Standardowy błąd estymacji & & 0,04 \\
\hline $\begin{array}{l}\text { Statystyka F } \\
\text { p-value }\end{array}$ & & 16,00670 \\
\hline $\begin{array}{l}\text { Test Durbina -Watsona } \\
\text { Statystka testowa DW } \\
\text { Seryjna korelacja }\end{array}$ \\
\hline $\begin{array}{l}\text { Test Shapiro-Wilka } \\
\text { Statystyka testowa SW } \\
\text { p-value }\end{array}$ & & 0,000003 \\
\hline
\end{tabular}

Źródło: opracowanie własne.

zobowiązaniami bieżącymi jest charakterystyczne dla strategii konserwatywnej zarządzania kapitałem obrotowym [Wędzki 2003, s. 129]. Rentowność aktywów oraz wskaźnik płynności bieżącej dodatnio oddziaływały na efektywność ekonomiczną przedsiębiorstw przemysłowych, znajdujących się w fazie wprowadzenia. Efektywne wykorzystanie środków gospodarczych oraz wzrost zdolności do regulowania zobowiązań bieżących i krótkoterminowych za pomocą majątku obrotowego przyczynią się do uzyskiwania wyższego poziomu efektywności ekonomicznej w przedsiębiorstwach przemysłowych, znajdujących się w fazie wprowadzenia.

\section{WNIOSKI}

W opracowaniu określono zmienne determinujące poziom syntetycznej miary efektywności ekonomicznej w spółkach giełdowych sektora przemysłu, znajdujących się w fazie wprowadzenia w ramach cyklu życia przedsiębiorstwa. Na podstawie przeprowadzonych badań sformułowano następujące wnioski: 
1. W przedsiębiorstwach przemysłowych będących w fazie wprowadzenia cyklu ich życia, po eliminacji zmiennych nieistotnych metodą regresji wstecznej, uzyskano model liniowy opisujący efektywność ekonomiczną z trzema statystycznie istotnymi następującymi zmiennymi objaśniającymi, tj. rentowność aktywów, relacja kapitału obrotowego netto do aktywów ogółem oraz wskaźnik płynności bieżącej. Wskaźnik rentowności aktywów oraz płynności bieżącej to determinanty, które wywierały dodatni wpływ na wzrost efektywności ekonomicznej przedsiębiorstw znajdujących się w fazie wprowadzenia, natomiast wskaźnik relacji kapitału obrotowego netto do aktywów ogółem ujemnie oddziaływał na zmienną objaśnianą.

2. Wśród czynników warunkujących poziom efektywności ekonomicznej przedsiębiorstw znajdujących się w fazie wprowadzenia znalazły się tylko uwarunkowania mikroekonomiczne o charakterze ilościowym (wielkości wymierne liczbowo), tj. rentowność aktywów, relacja kapitału obrotowego netto do aktywów ogółem oraz wskaźnik płynności bieżącej. Uwarunkowania makroekonomiczne nie miały istotnego wpływu na poziom efektywności ekonomicznej przedsiębiorstw znajdujących się $\mathrm{w}$ fazie wprowadzenia, natomiast mogły kształtować determinanty efektywności ekonomicznej w tych przedsiębiorstwach.

3. Uwarunkowania kształtujące poziom efektywności ekonomicznej przedsiębiorstw znajdujących się $\mathrm{w}$ fazie wprowadzenia można podzielić na stymulanty i destymulanty, co pozwala na ustalenie siły i kierunku wpływu uzyskanych w modelu ekonometrycznym zmiennych oddziałujących na poziom efektywności ekonomicznej. Pozwala to m.in. na usprawnienie procesu zarządzania przedsiębiorstwem, a także ukierunkowanie działań na te, które pozwalają na poprawę sytuacji badanych przedsiębiorstw w zakresie kształtowania poziomu ich efektywności ekonomicznej.

\section{Spis literatury}

ANTHONY J., RAMESH K. 1992: Associationbetween Accounting Performance Measures and Stock Prices, Journal of Accounting and Economics, s. 203-227.

BARBURSKI J. 2007: Struktura finansowania i jej wpływ na ekonomiczną efektywność działalności przedsiębiorstw, Zeszyty Naukowe Uniwersytetu Szczecińskiego, Prace Instytutu Ekonomiki i Organizacji Przedsiębiorstw, 50(2), s. 9-21.

BORKOWSKI B., DUDEK H., SZCZĘSNY W. 2003: Ekonometria. Wybrane zagadnienia, Wydawnictwo Naukowe PWN, Warszawa.

BOROWIECKI R., CZAJA J., JAKI A. 1998: Strategia gospodarowania kapitałem w przedsiębiorstwie. Zagadnienia wybrane, TNOiK, Warszawa-Kraków.

BULAN L., SUBRAMANIAN N., TANLU L. 2007: On the Timing of Dividend Initiations, Financial Management, 36(4), s. 31-65. 
CHĘCIŃSKI S. 2011: Istota oraz metody pomiaru efektywności gospodarowania w przedsiębiorstwie, Zeszyty Naukowe Uniwersytetu Szczecińskiego. Finanse, Rynki Finansowe, Ubezpieczenia, 37(639), s. 27-35.

CZECHOWSKI L. 1997: Wielowymiarowa ocena efektywności ekonomicznej przedsiębiorstwa przemysłowego, Wydawnictwo Uniwersytetu Gdańskiego, Gdańsk.

DE ANGELO H., DE ANGELO L., STULZ R. 2006: Dividend Policy and the Earned/Contributed Capital Mich: A Test of the Life cycle Theory, Journal of Financial Economics, 81(2), s. 227-254.

DICKINSON V. 2011: Cash Flow Patterns as a Proxy for Firm Life Cycle, The Accounting Review, 86(6), s. 1969-1994.

GORT M., KLEPPER S. 1982: Time paths in the diffusion of product innovation, Economic Journal, 92(367), s. 630-653.

JAKI A. 2006: Ocena efektywności a kreowanie wartości przedsiębiorstwa, Zeszyty Naukowe Akademii Ekonomicznej w Krakowie, 731, s. 107-121.

KOZUŃ-CIEŚLAK G. 2011: Przegląd metod pomiaru efektywności w aspekcie zastosowania do oceny działalności podmiotów sektora publicznego, Prace Naukowe Uniwersytetu Ekonomicznego we Wrocławiu, Nr 173, s. 90-100.

KUKUŁA K. 2000: Metoda unitaryzacji zerowanej, Wydawnictwo Naukowe PWN, Warszawa.

KULAWIK J. 2007: Wybrane aspekty efektywności rolnictwa, Zagadnienia Ekonomiki Rolnej, 1, s. 3-16.

MICHALAK J. 2008: Pomiar dokonań od wyniku finansowego do Balanced Scorecard, Difin, Warszawa.

MILEWSKI R., KAWIATKOWSKI E. (red.) 2005: Podstawy ekonomii, PWN, Warszawa.

OSBERT-POCIECHA G. 2010: Zdolność organizacji do zmian, Prace Naukowe Uniwersytetu Ekonomicznego we Wrocławiu, 144, s. 373-386.

PARKITNA A., ZIĘBA M. 2009: Wpływ kapitału pracującego na efektywność ekonomiczną przedsiębiorstw. Studium przypadku, [w] Zarządzanie finansami we współczesnych przedsiębiorstwach, Sierpińska M. (red.) Wyższa Szkoła Finansów i Zarządzania w Warszawie, Warszawa, s. 141-160.

PETROZOLIN-SKOWROŃSKA B. (red.) 1997: Nowa Encyklopedia Powszechna PWN. Tom 6.S-Z, Wydawnictwo Naukowe PWN, Warszawa.

PLATONOFF A.L., SYSKO-ROMAŃCZUK S. 2009: Dynamiczne funkcjonowanie przedsiębiorstwa, Zespół Badawczy „Integracja”, Wydział Nauk Ekonomicznych i Zarządzania Uniwersytetu Szczecińskiego, s. 4 (artykuł dostępny pod adresem: http://www.integracja.szczecin.pl/files/pdf/publikacje_naukowe_022.pdf).

SKORUPKA S. 1985: Słownik frazeologiczny języka polskiego. R/Ż, Wiedza Powszechna, Warszawa.

SKORUPA S., AUDERSKA H., ŁEMPICKA Z. (red.) 1968: Mały Słownik Języka Polskiego, PWN, Warszawa.

SOBOLEWSKI H. 1987: Wpływ przemian strukturalnych środków trwałych na ich efektywność w latach 1970-1980, [w] Badania nad efektywnością gospodarowania 
w przemyśle, Kurtysa E. (red.), Wydawnictwo Akademii Ekonomicznej w Poznaniu, Poznań, s. 150-180.

STANISZ A. 2007: Przystępny kurs statystyki z zastosowaniem Statistica PL na przykładach z medycyny. T. 2. Modele liniowe i nieliniowe, StatSoft Polska, Kraków.

SUCHECKI B. (red.) 2010: Ekonometria przestrzenna. Metody i modele analizy danych przestrzennych, CH Beck, Warszawa.

SZCZEPANKOWSKI P. 2013: Determinanty wartości rynkowej spółek kapitałowych wczesnej fazy rozwoju, Vizja Press \& IT, Warszawa.

SZYMAŃSKA E. 2010: Efektywność przedsiębiorstw - definiowanie i pomiar, Roczniki Nauk Rolniczych, Seria G, t. 97, z. 2, s. 152-164.

WĘDZKI D., 2003, Strategie płynności finansowej przedsiębiorstwa, Oficyna Ekonomiczna, Kraków.

WINKLER R. 2010: Efektywność - próba konceptualizacji pojęcia, Zeszyty Naukowe Uniwersytetu Ekonomicznego w Krakowie, 820, s. 102-115.

WARUSA WITHARANA M. 2012: Profitability and the Lifecyle of Firms, Finance and Economics Discussion Series from Board of Governors of the Federal Reserve System (U.S.) 63, s. $1-47$.

YAN Z., ZHAO Y. 2010: A New Methodology of Measuring Corporate Life-cycle Stages, International Journal of Economic Perspectives, 4(4), s. 579-587.

ZELIAŚ A. 2002: Metody statystyczne, PWE, Warszawa.

ZIMON G. 2014: Strategie zarządzania kapitałem obrotowym a płynność finansowa przedsiębiorstwa, Prace Naukowe Uniwersytetu Ekonomicznego we Wrocławiu, Rachunkowość a controlling, 344, s. 591-603.

\title{
DETERMINANTS OF THE ECONOMIC EFFICIENCY THE INDUSTRIAL ENTERPRISES IN THE INTRODUCTION STAGES OF THE COMPANY LIFE CYCLE
}

\begin{abstract}
The study identified a synthetic measure of the economic efficiency of enterprises, the variables determining its level were determined, and also the direction and strength of these variables were indicated on the size of the synthetic measure of this efficiency in industrial enterprises. Factors determining the level of economic effeciency of enterprises in the introduction phase are quantitative microeconomic factors. The return on assets and current liquidity ratio had to a positive impact on the increase in the economic efficiency of enterprises in the introduction stage, while the ratio of net working capital to total assets negatively had an effect to this efficiency.
\end{abstract}

Key word: economic efficiency of enterprises, the company life cycle stages. 